\title{
Regimes urbanos: perspectiva comparada entre operações urbanas consorciadas*
}

\author{
Urban regimes: a comparison between \\ urban consortium operations
}

Mônica de Carvalho [I]

\begin{abstract}
Resumo
Este artigo tem por objetivo a análise comparativa dos marcos legais das operações urbanas consorciadas dos municípios de Osasco e São Bernardo do Campo, ambos localizados na Região Metropolitana de São Paulo (RMSP), tendo por referência a perspectiva dos regimes urbanos. Pretendemos demonstrar que a escala geográfica promovida pela operação urbana consorciada é indicativa da maneira como se processa a relação entre o poder público e o setor privado, seja em direção à maior regulação da produção do espaço urbano, seja em direção à sua maior flexibilização.
\end{abstract}

Palavras-chave: operação urbana consorciada; regimes urbanos; políticas públicas urbanas.

\begin{abstract}
This article aims to compare the legal frameworks of urban consortium operations in the municipalities of Osasco and São Bernardo do Campo, both located in the Metropolitan Region of São Paulo, based on the perspective of urban regimes. We intend to demonstrate that the geographical scale promoted by the urban consortium operation is indicative of the way in which the relationship between the government and the private sector is processed, either towards greater regulation of urban space production or towards greater flexibility.
\end{abstract}

Keywords: urban consortium operation; urban regimes; public policies. 


\section{Introdução}

Este artigo tem por objetivo a análise comparativa dos marcos legais das operações urbanas consorciadas dos municípios de Osasco e São Bernardo do Campo, ambos localizados na Região Metropolitana de São Paulo (RMSP), visando articular o debate sobre regimes urbanos com a problemática da produção da escala geográfica, respectivamente referidos aos campos da ciência política e da geografia. Pretendemos demonstrar que a escala geográfica promovida pela operação urbana consorciada é indicativa da maneira como se processa a relação entre o poder público e o setor privado, seja em direção à maior regulação da produção do espaço urbano, seja em direção à sua maior flexibilização.

A proposição deste artigo é avançar na maneira com que as operações urbanas consorciadas (OUC) têm sido abordadas pelos estudos urbanos brasileiros. Ao incorporar a noção de regime urbano, pretende matizar as perspectivas que tendem a considerá-las por si sós uma forma de captura do Estado pelos interesses dos capitais urbanos. Para tanto, sugere a abordagem comparativa, fugindo à recorrência do estudo de caso, com a intenção de ir em busca da diversidade na apropriação desse instrumento urbanístico e do que a explique. Superar o estudo de caso decorre, ainda, da percepção obtida empiricamente de que as OUCs são promotoras de integração territorial, produzindo escalas que só podem ser identificadas se assumida a perspectiva para além dos limites administrativos dos municípios em que são operacionalizadas.

0 artigo desenvolve-se em três seções, além desta introdução e as considerações finais. Na primeira seção, demostramos como as operações urbanas consorciadas são objeto relevante para articular o debate entre regimes urbanos e a produção da escala geográfica; na seção seguinte, justificamos a constituição dos marcos legais das operações urbanas consorciadas de Osasco e São Bernardo do Campo como objetos privilegiados de análise; e, na terceira seção, comparamos os marcos legais das operações urbanas dos municípios selecionados, tomando a habitação de interesse social como indicador, para concluir pela sua diversidade, seja no que diz respeito à configuração da escala geográfica produzida, seja, como consequência, na forma como se dá o arranjo entre o poder público e o setor privado (capitais urbanos).

\section{A teoria dos regimes urbanos e a produção da escala geográfica}

A incorporação recente da teoria dos regimes urbanos aos estudos urbanos brasileiros pode ser interpretada como uma tendência no campo das ciências sociais de fugir às explicações generalistas que tendem a personificar tanto o Estado (o ser do Estado, no dizer de Bourdieu) ${ }^{1}$ como o capital, quase sempre tornado sujeito onipresente nos estudos vinculados à tradição do marxismo estruturalista. ${ }^{2}$ Vai ao encontro, portanto, do objetivo de explicitar a diversidade dos atores que representam os diferentes interesses, tanto públicos como privados, esmiuçando a forma como se articulam. No entanto, a ênfase na agência não significa, de forma alguma, o abandono da perspectiva estrutural, nem tampouco crítica, o que fica evidente quando se interroga o momento em 
que a teoria dos regimes urbanos se constituiu. Sem pretender recuperar a discussão exaustiva sobre o tema, basta chamar a atenção para alguns pontos do debate que terminam por revelar que a teoria dos regimes urbanos está diretamente associada a um período histórico específico que constituiu uma tensão entre governo local e o capital urbano. Para compreender esse aspecto, é preciso não descuidar da adjetivação atribuída ao regime: trata-se antes de um regime urbano.

Em que pese a noção de regime urbano ter se originado de um estudo empírico realizado na cidade de Atlanta, com todas as peculiaridades dos arranjos institucionais próprios às cidades americanas, o que lhe rendeu objeções a sua transposição para outros cenários (Le Galès, 1995, pp. 85-89), ${ }^{3}$ o que estava em jogo era encontrar um "meio-termo" entre as abordagens pluralistas, cuja ênfase recai na multiplicidade dos atores sociais e políticos na sua relação com o Estado, ainda que as empresas privadas tivessem aí proeminência, e a tese defendida por Molotch (1976) de que as cidades teriam se transformado em "máquinas de crescimento", abordagem de cunho estruturalista tendente a considerar o Estado refém da pressão dos interesses dos capitais urbanos (ibid., pp. 79-85; Mossberger e Stoker, 2001, pp. 812 e 819; Marques, 2016, pp. 23-24). Com a noção de regime urbano, Stone (1993) pretendia introduzir a possibilidade de ir além da determinação dos "negócios" sobre as políticas produzidas pelo Estado. No dizer de Marques (2016, p. 24), "dependendo das condições locais, as coalizões poderiam impulsionar várias agendas e políticas diferentes, desde máquinas de crescimento (para ele [Stone] 'regimes de desenvolvimento') até anti-grown machines ('regimes de preservação')".
Ao que parece, portanto, a noção de regime urbano abre-se antes para pensar a relação entre o poder público e o setor privado, evitando, a priori, a determinação de um sobre o outro; criando, nesse sentido, a possibilidade de que seja identificada variedade possível de arranjos. No entanto, se isso é verdade, é importante atentar para o alerta feito por Mossberger e Stoker: diante do uso indiscriminado da ideia de regime urbano, levando a uma extensão indesejada do conceito, é preciso lembrar que para Stone, segundo eles, "por causa dos recursos que controla, os negócios são participantes-chave na coalizão" (Mossberger e Stoker, 2001, p. 813; tradução da autora). Ou seja, se a noção de regime urbano matiza a ideia de captura do Estado pelos interesses do setor privado, não significa negá-los, ao contrário, trata-se de esmiuçá-los. Ainda com Mossberger e Stoker, para que a noção de regime urbano seja mobilizada, é preciso que haja uma parceria entre atores provenientes de fontes governamentais e não governamentais, exigindo, embora não se limitando, a participação de negócios (ibid., p. 829; grifos nossos).

Isto nos coloca diante de uma questão que precisa ser considerada. Se é verdade que a proposição de Stone se contrapõe àquelas abordagens já mencionadas, a procura de um campo de análise intermediário não seria pela intenção de enfatizar a participação dos interesses do setor privado na definição das políticas públicas, pois aquela já era o centro das teorias por ele objetadas, sobretudo a da "máquina de crescimento". Ao enfatizar a relação entre poder público e setor privado, parece mais razoável que Clarence Stone estivesse, antes, querendo sugerir que o Estado teria ainda algum papel. Nesse sentido, não se trata 
apenas de matizar e explicitar mais claramente quais atores representariam o interesse do setor privado, mas também constituir a possibilidade de ações diversas do Estado nessa "parceria". Sendo assim, não faz muito sentido as objeções feitas à sua proposição de que o Estado estaria sendo pouco tematizado (Marques, 2016, p. 24), pois a ênfase na relação, no nosso modo de entender, é exatamente para sugerir que também a ação do Estado deve ser observada na sua especificidade. Da mesma forma, fragiliza-se a observação de que a noção de regime urbano não poderia ser transposta para situações em que o papel regulador do Estado ainda tivesse relevância (Le Galès, 1995, p. 89), pois parece ser plenamente cabível considerar a relação entre poder público e setor privado com o peso da balança pendendo a favor da regulação.

Não se trata, obviamente, dos mesmos processos de regulação que antecedem ao processo histórico que constituiu as bases para uma pressão maior dos interesses privados sobre as políticas públicas urbanas, mas desconsiderar a relação entre poder público e setor privado parece ir ao encontro das teorias que se posicionam apenas do lado da extensão do poder privado sobre o Estado (a captura do Estado). Incorporar a noção de regime urbano só faz sentido se o objetivo for, antes, inserir tensão onde até então parecia apenas determinação de um campo sobre o outro. Assim, é preciso também matizar a ideia de parceria. Quando a ênfase recai sobre a relação, pode haver parceria, mas pode haver, também, tensão e conflito. Só dessa forma compreendo que a noção de regime urbano enriquece as discussões que temos feito até o momento.

Iludem-se aqueles que, porventura, venham a entender esse posicionamento na fronteira da balança como um enfraquecimento da postura crítica. E é aqui que a discussão sobre regime urbano se encontra com a problemática da produção da escala geográfica.

Seria importante lembrar que a discussão de regimes urbanos, proposta em 1989 por Stone, vem na esteira de um conjunto de estudos produzidos durante a década de 1970 - incluindo as teorias pluralistas e a teoria da "máquina de crescimento" ${ }^{4}$ - que estava problematizando os processos de desindustrialização nas cidades americanas e a crise fiscal daí decorrente (Hall, 2011, pp. 407-408). A "receita mágica" da parceria viria em socorro da necessidade de revitalização urbana exatamente das cidades que perderam espaço como centralidade das atividades industriais (ibid., p. 412).

Mais tarde, o processo de reconversão da atividade econômica dessas grandes cidades seria tematizado por Sassen (1998), com um novo ingrediente: a disputa pelo capital internacional desses espaços urbanos desvitalizados, sobretudo por aquele ligado às atividades da economia terciária globalizada. No entanto, se, por um lado, Sassen avançava no sentido de demonstrar que capitais desenraizados não prescindiam de território, por outro, concentrava sua análise naquilo que ia sobre o espaço urbano, desencadeando, inclusive, estudos decorrentes que teimariam em classificar as cidades em torno da tipologia de cidade global, considerando as características por ela criadas.

Em outro momento, já tivemos oportunidade de apontar para a transposição postiça do conceito de cidade global para as nossas metrópoles (Carvalho, 2000), embora não estivesse ainda muito claro a que se devia esse desencontro. Hoje, parece cada vez mais 
evidente que o desencontro provinha do fato de que não se verificava no Brasil, sobretudo em São Paulo - centro da industrialização brasileira -, o que estava na base daquelas teorias, ou seja, o processo de desindustrialização e que só recentemente nos viria alcançar. ${ }^{5}$

No entanto, é exatamente esse processo que permite articular todas as teorias que temos até o momento importado, sem que as condições de sua apropriação estivessem postas. Dito de outra forma: há tempos nos apropriamos dos conceitos de máquina de crescimento, cidade global, planejamento estratégico, pareceria público-privada esquecendo-nos de que, de alguma forma, estão todos eles referidos ao mesmo processo histórico: a reconversão econômica das grandes cidades. Sem considerar esse aspecto, terminamos por fragmentar a discussão e deixar de articular o que precisa ser articulado para compreender o processo na sua totalidade.

Ao recuperar o que está na base da produção daqueles conceitos é que se pode compreender qual o sentido de também nos apropriarmos da noção de regime urbano e fazê-lo da maneira matizada conforme o próprio surgimento da noção sugere. Pois então vejamos.

0 processo de desindustrialização, ou de desconcentração industrial, com a migração de plantas industriais para outras cidades e regiões, libera extensas áreas de alto valor fundiário, considerando as várias camadas de investimento em infraestrutura urbana produzidas ao longo de quase um século. É em torno da disputa pela apropriação dessa mais-valia urbana liberada com o processo de reconversão econômica que se evidenciam os atores. De um lado, aqueles que têm algo a lucrar com a apropriação da mais-valia urbana e que são os produtores diretos do espaço urbano: o capital vinculado às incorporadoras e agentes imobiliários (capital incorporador) (Marques, 2016, p. 20). De outro lado, o Estado, que, nesse caso, também não pode ser apreendido na sua generalidade. Se Sassen estava correta a alertar para territorialização necessária do capital global, ao propor a ideia de cidade global, no entanto, deixava de considerar que a forma assumida por esse território pode ter escalas diversas, se consideramos a produção do espaço urbano e não somente a localização das atividades econômicas (Carlos, 2014, pp. 52-73). Nesse sentido, se as áreas liberadas pelas plantas industriais estão forçosamente localizadas em territórios municipais, nada indica que os novos capitais ali investidos tenham o município por referência, sobretudo se estamos falando de capitais urbanos que hoje não se atêm exclusivamente à produção de espaço urbano como valores de uso de consumo local, mas antes, senão prioritariamente, como ativos financeiros. E, nesse caso, são novamente o capital incorporador e imobiliário articulados que têm proeminência (Fix, 2007).

Materialmente o espaço pode ser necessário, o território não. Um território pode ser apenas um espaço liso da perspectiva do capital desenraizado. Ou, melhor dizendo, pode apenas ser considerado da perspectiva dos interesses do próprio capital: mais o espaço de fluxos, menos as hinterlândias (Castells, 2008, pp. 467-521).

Nesses termos, a reconversão econômica pode não ser apenas uma mudança da atividade econômica que vai sobre o espaço, mas pode ser também uma mudança na produção da escala geográfica desse mesmo espaço (Smith, 2000, p. 137). Dependendo de como essa escala seja projetada, pode 
significar a fragmentação do território em direção a uma escala sobre a qual o poder local não tem mais controle.

Articulam-se, dessa forma, a noção de regime urbano com a produção da escala geográfica. Se a noção de regime urbano está diretamente associada aos processos de desindustrialização das antigas metrópoles, constituindo a necessidade de mobilizar capitais urbanos na produção do espaço urbano, a escala resultante da produção do espaço urbano para as novas atividades da economia globalizada, seja a que vai sobre o espaço, seja a tem no próprio espaço a condição de reprodução do capital (espaço como ativo financeiro), indica o quanto a balança oscila tanto em direção aos interesses públicos, quanto em direção aos interesses do capital urbano. Pois quanto mais abstraída territorialmente a escala geográfica, quanto mais o capital urbano "salta escalas" (Smith, 2000, p. 137; Sposito, 2014, p. 132), menos o poder local tem controle sobre a produção do espaço urbano.

Ora, se o poder local, no nosso caso municipal, organiza-se para confrontar, na mesma escala, o poder do capital urbano, não seria essa uma forma de recuperar para si a apropriação da mais-valia urbana? Essa pergunta só é possível se partimos da premissa de que entre poder público (especificado como poder local/ municipal) e setor privado (agora especificado como capital urbano) há tensão e conflito e não pura determinação.

Para o caso brasileiro, as operações urbanas consorciadas são excelente objeto para observar como se processa o regime urbano: a) desde sua origem na cidade de São Paulo, configuram-se como um arranjo ${ }^{6}$ entre o poder público municipal e o capital urbano; b) a partir de um determinado momento, passam a ser mobilizadas como indutores dos processos de reconversão econômica dos municípios que tinham centralidade na atividade industrial, incluindo São Paulo; c) promovem integração territorial que, conforme se configura, projetam o território do município para outra escala, para além das suas divisões administrativas; d) são oriundas de marcos regulatórios por meio dos quais é possível identificar a motivação do poder municipal ao lançar mão desse instrumento.

As três primeiras características são comuns aos estudos de operações urbanas consorciadas. No entanto, a ênfase na ideia de parceria e a predominância dos estudos que consideram aprioristicamente que as operações urbanas são em si mesmas capturas do Estado pelo capital privado impedem de ressaltar que, antes de tudo, as operações urbanas são marcos regulatórios e, mais do que isso, marcos regulatórios que passaram por modificações desde a sua origem que dizem exatamente da disputa em torno da sua regulação. Desconsiderar isso enfraquece a discussão política, pois ignora a importância que a regulação pública tem no sentido de frear a desregulação exigida em tempos de neoliberalismo exacerbado. É no ato de ressaltar a relevância que o Estado ainda tem nos arranjos entre poder público e o setor privado que a crítica se reinstala e aponta para as possibilidades de reversão da apropriação privada indevida da produção do espaço urbano em nossas cidades. 


\section{As operações urbanas consorciadas na Região Metropolitana de São Paulo}

Inicialmente, foi feito levantamento das OUCS planejadas (Plano Diretor) e/ou com legislação específica (LE) nos municípios da RMSP, conforme exposto na Tabela 1.

Com base nesse levantamento, observa-se a capilaridade do instrumento das OUCS, cuja origem data do início da década de 1990, no município de São Paulo. Embora haja estudos que procurem projetar sua origem para períodos anteriores, gostaríamos de defender que a aproximação de diferentes experiências tende a obscurecer o que estava em jogo no momento em que as operações urbanas Faria Lima (1995), Água Branca (1995) e Centro (1997) foram aprovadas na cidade de São Paulo.

Em primeiro lugar, é preciso lembrar que aquela década testemunharia o embate em torno da regulamentação dos artigos de Política Urbana (art. 182 e 183) da Constituição Federal de 1988 (CF88) (Maricato, 2000) que, pela primeira vez no País, instituía como direito constitucional a função social da propriedade; embate que, por sua vez, desembocaria na aprovação do Estatuto da Cidade, em 2001. Nesse hiato é que aquelas operações urbanas foram aprovadas, num claro confronto aos possíveis limites que seriam impostos à apropriação desigual da terra urbana, uma vez promulgada a lei federal (Carvalho, 2012).

Em segundo lugar, as operações urbanas aprovadas na gestão de Paulo Maluf (1993-1996) e de seu sucessor Celso Pitta (1997-2000) introduziram uma nova forma de financiamento do poder público, pela venda de potencial construtivo para além do previsto no zoneamento da cidade, com o claro objetivo de atrair o capital urbano. Também, nessas gestões, foram criados os Certificados de Potencial Adicional de Construção (Cepac), por ocasião da Operação Urbana Faria Lima, que, embora não tenham sido regulamentados naquele momento (Maleronkae e Hobbs, 2017, p. 27), deram os primeiros passos em direção à financeirização da terra urbana.

Por fim, e não menos importante, é preciso ressaltar que as primeiras experiências de articulação com capital urbano, datadas de 1985 , tinham como contrapartida a construção de moradias de interesse social, o que foi completamente esquecido naquelas aprovadas a partir de 1995, cuja legislação sequer tratava do tema ou o fazia marginalmente, postergando sua solução para legislações posteriores, como foi possível observar na legislação da Operação Urbana Centro de 1997 (Carvalho, 2012).

O fato consumado pela aprovação das operações urbanas em São Paulo não deixou outra saída senão a sua incorporação ao Estatuto da Cidade, em 2001, ainda que com ênfases diversas sobre o que era preconizado pela legislação paulistana, tentando, de alguma forma, retomar o controle da relação entre o poder público e o setor privado. Ainda assim, deixou uma série de brechas, como a ausência de uma clara regulamentação dos Cepacs, também incorporados pela legislação federal, com a possibilidade, inclusive, de que fossem negociados pelos municípios como títulos mobiliários (Maleronka e Hobbs, 2017, p. 29).

O município de São Paulo, portanto, não só esteve no centro da introdução das operações urbanas como meio de financiamento do poder municipal pelo capital urbano, como o fez no confronto direto com o marco 
Tabela 1 - Operações Urbanas Consorciadas na RMSP

\begin{tabular}{|c|c|c|c|c|c|}
\hline Municípios & População* & $\begin{array}{c}\text { Densidade } \\
\text { Demográfica } \\
2017\left(\mathrm{hab} . / \mathrm{km}^{2}\right)^{*}\end{array}$ & $\begin{array}{c}\text { PIB } 2015 \\
\text { (em mil reais)* }\end{array}$ & $\begin{array}{l}\text { Distância até São } \\
\text { Paulo }(\mathrm{km})^{* *}\end{array}$ & $\begin{array}{l}\text { Operação } \\
\text { Urbana*** }\end{array}$ \\
\hline São Paulo & 12.106 .920 & $7.959,27$ & 650.544 .789 & & LE \\
\hline $\begin{array}{l}\text { Arujá } \\
\text { Biritiba-Mirim } \\
\text { Ferraz de Vasconcelos } \\
\text { Guararema } \\
\text { Guarulhos } \\
\text { Itaquaquecetuba } \\
\text { Mogi das Cruzes } \\
\text { Poá } \\
\text { Salesópolis } \\
\text { Santa Isabel } \\
\text { Suzano }\end{array}$ & $\begin{array}{r}86.430 \\
31.793 \\
188.868 \\
28.978 \\
1.349 .113 \\
360.657 \\
433.901 \\
115.488 \\
16.903 \\
56.014 \\
290.769\end{array}$ & $\begin{array}{r}898,75 \\
100,17 \\
6.388,45 \\
107,00 \\
4.233,51 \\
4.365,14 \\
608,95 \\
6.689,53 \\
39,77 \\
154,17 \\
1.409,88\end{array}$ & $\begin{array}{r}4.874 .536 \\
723.190 \\
2.736 .076 \\
1.549 .436 \\
52.199 .130 \\
6.476 .632 \\
14.130 .976 \\
4.393 .670 \\
193.193 \\
1.514 .766 \\
10.328 .167\end{array}$ & $\begin{array}{c}45 \\
79 \\
45 \\
79 \\
16 \\
36 \\
57 \\
42 \\
101 \\
61 \\
44\end{array}$ & $\begin{array}{c}\text { Não } \\
\text { Não } \\
\text { Não } \\
\text { PD (2006) } \\
\text { Não } \\
\text { Não } \\
\text { Não } \\
\text { PD (2006) } \\
\text { Não } \\
\text { Não } \\
\text { PD (2004/2015) }{ }^{(a)}\end{array}$ \\
\hline Total Sub-Região Leste & 2.958 .914 & $1.042,01$ & 99.119 .772 & & $27,3 \%$ \\
\hline $\begin{array}{l}\text { Caieiras } \\
\text { Cajamar } \\
\text { Francisco Morato } \\
\text { Franco da Rocha } \\
\text { Mairiporã }\end{array}$ & $\begin{array}{r}98.223 \\
73.921 \\
171.602 \\
149.502 \\
95.601\end{array}$ & $\begin{array}{r}1.005,95 \\
562,62 \\
3.502,01 \\
1.125,98 \\
298,10\end{array}$ & $\begin{array}{r}3.074 .160 \\
11.584 .946 \\
1.337 .906 \\
2.743 .594 \\
1.514 .466\end{array}$ & $\begin{array}{l}38 \\
41 \\
48 \\
47 \\
37\end{array}$ & $\begin{array}{c}\text { LE } \\
\text { PD (2007/2014) } \\
\text { PD (2006) } \\
\text { PD (2007/2015) } \\
\text { Não }\end{array}$ \\
\hline Total Sub-Região Norte & 588.849 & 804,99 & 20.255 .072 & & $80 \%$ \\
\hline $\begin{array}{l}\text { Barueri } \\
\text { Carapicuíba } \\
\text { Itapevi } \\
\text { Jandira } \\
\text { Osasco } \\
\text { Pirapora do Bom Jesus } \\
\text { Santana de Parnaíba }\end{array}$ & $\begin{array}{r}267.534 \\
396.587 \\
229.502 \\
121.492 \\
697.886 \\
18.174 \\
131.887\end{array}$ & $\begin{array}{r}4.071,99 \\
11.479,97 \\
2.776,52 \\
6.962,69 \\
10.744,31 \\
167,52 \\
732,91\end{array}$ & $\begin{array}{c}47.793 .106 \\
5.115 .509 \\
10.278 .995 \\
3.291 .026 \\
65.872 .535 \\
371.896 \\
7.832 .605\end{array}$ & $\begin{array}{l}30 \\
26 \\
40 \\
34 \\
22 \\
55 \\
40\end{array}$ & $\begin{array}{c}\text { PD (2014/2014) } \\
\text { PD (2010) } \\
\text { Não } \\
\text { PD (2006) } \\
\text { LE } \\
\text { Não } \\
\text { Não }\end{array}$ \\
\hline Total Sub-Região Oeste & 1.863 .062 & $3.364,47$ & 140.555 .672 & & $57,1 \%$ \\
\hline $\begin{array}{l}\text { Diadema } \\
\text { Mauá } \\
\text { Ribeirão Pires } \\
\text { Rio Grande da Serra } \\
\text { Santo André } \\
\text { São Bernardo do Campo } \\
\text { São Caetano do Sul }\end{array}$ & $\begin{array}{r}417.869 \\
462.005 \\
121.848 \\
49.408 \\
715.231 \\
827.437 \\
159.608\end{array}$ & $\begin{array}{r}13.586,58 \\
7.462,65 \\
1.229,86 \\
1.359,57 \\
4.068,85 \\
2.020,56 \\
10.410,80\end{array}$ & $\begin{array}{r}13.854 .570 \\
12.429 .673 \\
2.813 .436 \\
533.254 \\
26.240 .885 \\
42.745 .533 \\
13.302 .120\end{array}$ & $\begin{array}{l}21 \\
27 \\
55 \\
50 \\
24 \\
19 \\
14\end{array}$ & $\begin{array}{c}\text { PD (2008/2015) } \\
\text { LE } \\
\text { LE } \\
\text { PD (2006) } \\
\text { PD (2004/2012) } \\
\text { LE } \\
\text { PD }(2006 / 2010)\end{array}$ \\
\hline Total Sub-Região Sudeste & 2.753 .406 & $3.322,55$ & 111.919 .471 & & $100,0 \%$ \\
\hline $\begin{array}{l}\text { Cotia } \\
\text { Embu das Artes } \\
\text { Embu-Guaçu } \\
\text { Itapecerica da Serra } \\
\text { Juquitiba } \\
\text { São Lourenço da Serra } \\
\text { Taboão da Serra } \\
\text { Vargem Grande Paulista }\end{array}$ & $\begin{array}{r}237.750 \\
267.054 \\
68.270 \\
170.927 \\
31.027 \\
15.465 \\
279.634 \\
50.346\end{array}$ & $\begin{array}{r}733,81 \\
3.793,49 \\
438,64 \\
1.133,90 \\
59,42 \\
82,94 \\
13.715,62 \\
1.184,92\end{array}$ & $\begin{array}{r}10.639 .278 \\
9.403 .920 \\
1.001 .844 \\
3.200 .863 \\
441.964 \\
207.484 \\
7.709 .489 \\
1.948 .504\end{array}$ & $\begin{array}{l}31 \\
27 \\
49 \\
34 \\
72 \\
54 \\
30 \\
44\end{array}$ & $\begin{array}{c}\text { LE } \\
\text { LE } \\
\text { PD (2007) } \\
\text { LE } \\
\text { Não } \\
\text { Não } \\
\text { PL (2006) } \\
\text { PL (2013) }\end{array}$ \\
\hline Total Sub-Região Sudoeste & 1.120 .473 & 761,05 & 34.553 .345 & & $75 \%$ \\
\hline RMSP & 21.391 .624 & & & & \\
\hline Estado de São Paulo & 45.094 .866 & & & & \\
\hline
\end{tabular}

* Fonte IBGE - Elaboração Emplasa.

** Fonte DER - Elaboração Emplasa.

*** Fonte IBGE - Elaboração própria.

Legenda: LE - Legislação específica PD - Plano diretor

(a) - Quando houver duas datas indicadas no Plano Diretor, a primeira refere-se a sua criação, e a outra, à atualização. 
regulatório que começava a se impor contra a expansão do capital imobiliário sobre a terra urbana. As operações urbanas desencadeadas, a partir de 1985 , não sofriam o mesmo constrangimento da CF88, como as que foram aprovadas a partir de 1995. Da mesma forma, em 1985, os municípios não estavam submetidos à responsabilidade fiscal que começava a ganhar contornos em 1995. Assim, é possível aventar a hipótese de que as operações urbanas em São Paulo sejam, ao mesmo tempo, produto do maior controle fiscal sobre os municípios impostos pelo governo federal, mas também da sua omissão em relação às políticas de desenvolvimento urbano (Arretche, 2012), pelo menos até o ano de 2001, quando foi, então, aprovado o Estatuto da Cidade.

Os dados apresentados na Tabela 1 precisam ser lidos, pois, considerando a centralidade de São Paulo. Não só porque foi o município que tomou a iniciativa de financiar o poder público por meio de uma aliança clara com o capital urbano, mas também, e exatamente por isso, como o que produziu espaço, conforme esses mesmos interesses. Nesse sentido, os perímetros demarcados das OUCs indicam a marcha do capital urbano, que, como já dissemos mais acima, não se limita às

Figura 1 - OUC nos municípios da RMSP

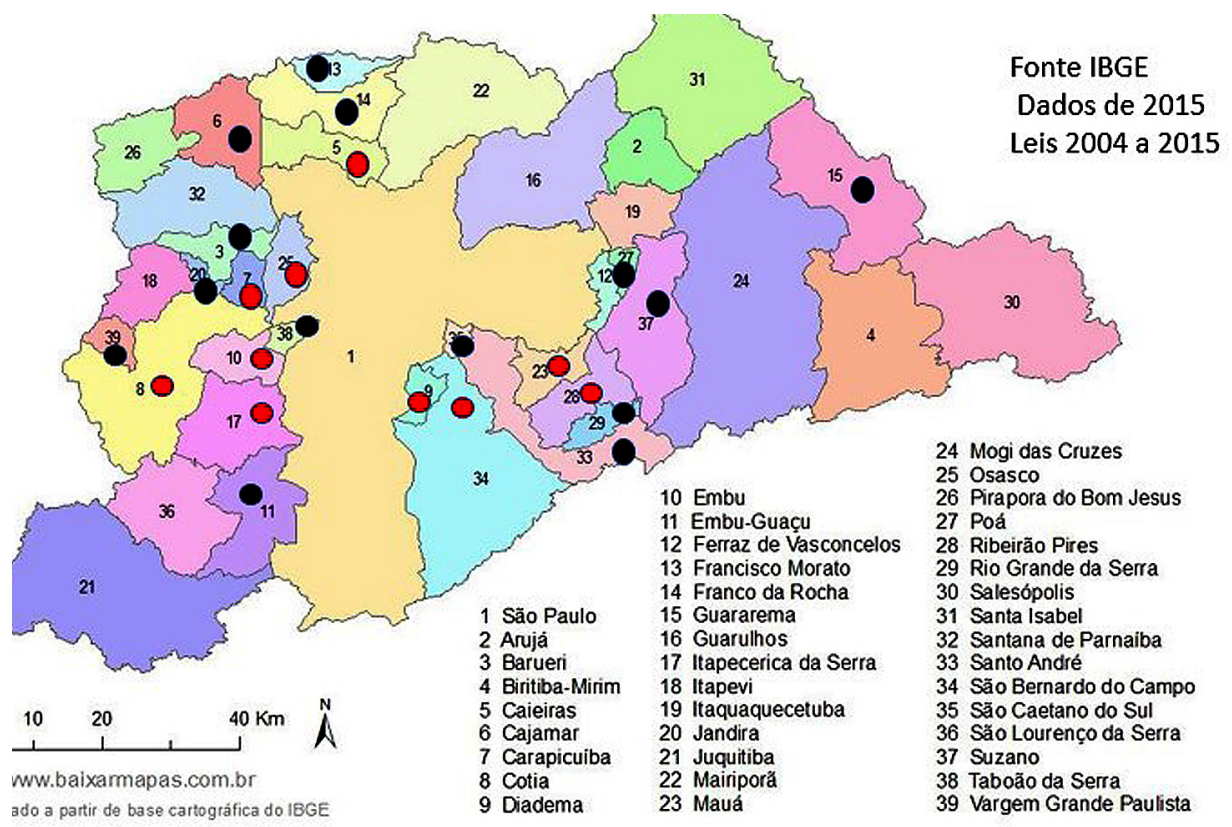

Fonte: IBGE Cidades. Elaboração própria.

Legenda: OUC em Plano Diretor

OUC em Lei Específica 
divisões político-administrativas, mas, ao contrário, procura rompê-las no interesse de potencializar a valorização de áreas por meio de sua integração.

Assim, não parece irrelevante o fato de que os municípios que mais rapidamente aprovaram leis específicas sobre a OUC sejam aqueles que fazem divisa com o município de São Paulo (Figura 1). E, como será possível demonstrar mais adiante, obedecendo a eixos por ela delineados, o que reforça a ideia de integração territorial por meio das OUCs, tendo o município-polo como núcleo de expansão.

Observando mais detidamente os dados apresentados na Tabela 1, nos 39 municípios da RMSP, 14 deles, ou 35,9\%, não possuem o instrumento urbanístico da operação urbana consorciada; 16 dos municípios da RMSP, ou $41 \%$ deles, têm o instrumento especificado no Plano Diretor (PD); 9 deles, ou 23,1\%, possuem legislação específica (LE) para operação urbana. Considerando que a LE pressupõe a indicação do instrumento no PD, é possível compreender a Figura 1 em suas diferentes temporalidades, o que dá a exata medida da centralidade do município de São Paulo, legitimando a hipótese de que se trata da expansão do instrumento urbanístico e de um tipo de apropriação territorial, a partir do município-polo. Isto é, a presença da OUC pode estar associada à maior conurbação urbana ligada à interfuncionalidade do uso do solo, conforme os interesses do capital urbano.

Observa-se, também, uma distribuição desigual na apropriação do instrumento, considerando as Sub-regiões da RMSP, com 100\% de apropriação do instrumento na Sub-região Sudeste, $80 \%$ na Sub-região Norte, $75 \%$ na Sub-região Sudoeste, $57,1 \%$ na Sub-região Oeste, e apenas $27,3 \%$ na Sub-região Leste.
Surpreende a Sub-região Sudeste, não só pelo fato de todos os municípios terem se apropriado do instrumento, mas por $50 \%$ deles possuírem operações urbanas em legislação específica. Levando-se em conta que a Sub-região Sudeste foi tradicionalmente o berço da indústria paulista, levantamos inicialmente a hipótese de que a expansão do instrumento urbanístico estaria associada a processos de reconversão econômica.

Partindo da premissa da centralidade de São Paulo, buscamos identificar o que estava sendo proposto para a cidade, com base em seu PD, de maneira a verificar se haveria alguma continuidade no território dos municípios vizinhos.

A Figura 2, presente no Plano Diretor Estratégico da Cidade de São Paulo, evidencia as OUCs em andamento e as previstas, no ano de 2002, quando o Plano Diretor foi aprovado. Para além da OUC Jacu-Pêssego, que corta a Zona Leste em toda a sua extensão no sentido norte-sul, todas as demais acompanhavam antigos territórios industriais, sugerindo um processo de reconversão econômica, dado que, desde o início dos anos 2000, São Paulo vem passando por um processo de desconcentração industrial. 0 eixo Sudeste (em rosa no mapa) desembocava exatamente nos municípios pertencentes à região do Grande $A B C$, mais especificamente nas divisas de Diadema e São Bernardo do Campo. No extremo oposto desse mesmo eixo, a Oeste, encontramos a divisa de Osasco. Se nossa hipótese estiver correta, a existência de OUC em São Paulo estimularia a sua reprodução nos municípios que the fazem contiguidade. No caso de Osasco, essa hipótese é quase evidente, pois sua Lei Específica data de 2008. No caso de São Bernardo do Campo, no entanto, a lei específica é bem mais 
Figura 2 - Operações Urbanas em São Paulo - 2002

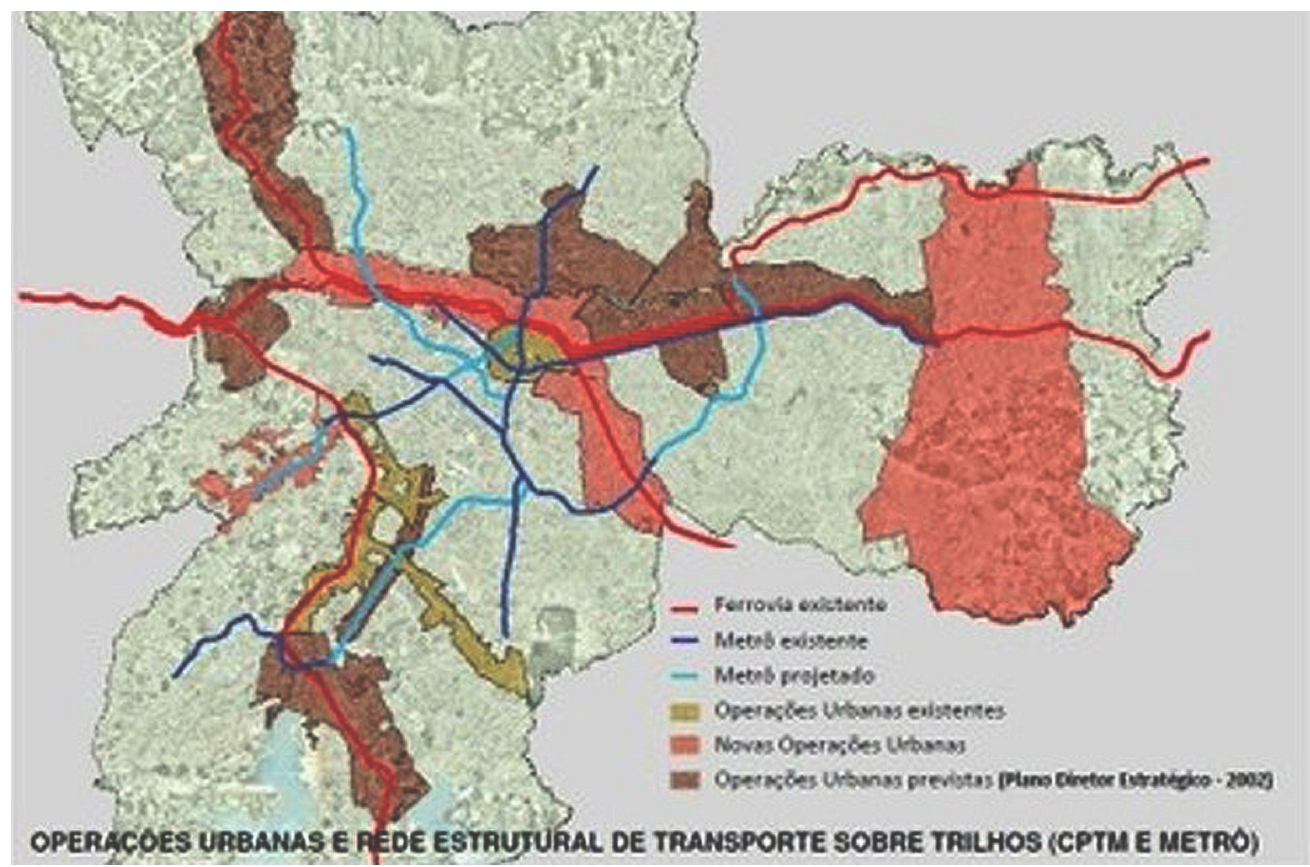

Fonte: Plano Estratégico da Cidade de São Paulo (2002).

tardia, de 2015. Essa diferença na datação da lei de cada município parece indicar uma relação diversa dos municípios em relação a São Paulo, no que diz respeito às OUCs.

Em vista disso é que foram escolhidos exatamente os municípios de Osasco e São Bernardo do Campo para a análise comparativa, não só por apresentarem clara continuidade territorial com o que estava sendo previsto para São Paulo, mas, sobretudo, porque, ao mesmo tempo, as OUCs estariam de alguma forma articuladas ao processo de reconversão econômica.
A partir de uma análise inicial, logo foi possível perceber a diferença no comportamento das OUCs que seguiam o Eixo da Sub-região Oeste, envolvendo os municípios de Osasco, Barueri, Carapicuíba e Jandira, e aquelas delimitadas no eixo da Sub-região Sudeste, englobando os municípios de Diadema, São Bernardo do Campo, São Caetano, Mauá, Santo André, Rio Grande da Serra e Ribeirão Pires. Se, no eixo Oeste, o perímetro das áreas demarcadas sugeria contiguidade de um município em relação ao outro e de todos em relação a São Paulo, essa contiguidade não parecia ser 
assim tão evidente no eixo Sudeste. Ao contrário, a OUC parecia ter sido pensada muito mais tendo por objeto o ordenamento territorial da própria região, o chamado Grande $A B C$, do que por alguma intervenção proposta no território imediatamente contíguo da cidade de São Paulo.

Essa primeira observação levou ao estabelecimento de novas hipóteses, vinculadas à questão da integração territorial. Nos dois casos, as OUCs operam na direção de integrar os municípios, tendo São Paulo como referência, mas com sentidos diversos. No primeiro caso, na Sub-região Oeste, a integração seria dada no sentido centro-periferia, o município-polo sendo forte indutor das OUCs planejadas para os municípios a ele pertencentes. Hipótese que ganha força, considerando que esse eixo é conhecido como apêndice imobiliário da cidade de São Paulo, como se notabilizou o município de Barueri, submerso em sua nova identidade Alphaville. No caso do Eixo Sudeste, ao contrário, o que parecia estar havendo era uma integração entre os municípios propriamente ditos, mais especificamente aqueles que fazem fronteira entre si, como é o caso de Diadema, São Bernardo, São Caetano do Sul e Santo André, hipótese que também tem sua história, pois que foi exatamente entre esses municípios, mais Mauá, Ribeirão Pires e Rio Grande da Serra, que se estabeleceu a primeira experiência de cooperação intermunicipal, o Consórcio do $A B C$, oficializado em 19 de dezembro de 1990 (Abrucio e Soares, 2001, p. 160). Nesse caso, a relação com o município-polo é diversa, já que a articulação regional visava, antes, fortalecer a possibilidade de resposta local aos problemas locais, como aqueles decorrentes da proteção aos recursos hídricos, mas também ao processo em andamento de desindustrialização que, desde a década de 1980, vinha sendo vivido pela região berço da indústria automobilística brasileira (ibid., pp. 151-152).

A questão da reconversão econômica também ganhava força, portanto, nos dois eixos, embora no eixo Oeste dissesse respeito exclusivamente ao município de Osasco. Pretendendo, portanto, articular as duas hipóteses - a OUC como meio de induzir a reconversão econômica e promover a integração territorial - é que foram escolhidos os municípios de Osasco e São Bernardo do Campo. Ao escolher esses municípios fica clara a intenção comparativa, pois se trata de interrogar se a história objetivada (Bourdieu, 2009, p. 94) de cada um dos municípios interfere na maneira como se estruturam as OUCs, dando os primeiros passos para pensar a especificidade do regime urbano.

\section{Regime urbano e escala geográfica em Osasco e São Bernardo do Campo}

A dimensão das áreas demarcadas para as respectivas OUCs assume relevância quando em relação à área do município. A área de SBC é de 409,532 km², o que significa que a OUC se apropria de $5 \%$ de seu território, o que parece ser uma porção bastante considerável se comparada a Osasco, cuja dimensão territorial de $64,954 \mathrm{~km}^{2}$ é ocupada por $1,7 \%$ das duas OUCs somadas. Aqui vale uma ressalva: se a hipótese de integração territorial se confirma, a menor extensão pode significar que ela adquire sentido somente quando articulada às demais OUCs. Na minha hipótese, a área de Osasco é 


\section{Quadro 1 - Área das OUC em Osasco e SBC}

Operação Consorciada Tietê I - área de 0,48 km² (Osasco)

Operação Consorciada Tietê II - área de $0,6 \mathrm{~km}^{2}$ (Osasco)

Operação Consorciada São Bernardo do Campo - área de 20,5 km² (SBC)

menor porque, nesse eixo, serão somadas em contiguidade as OUC de Carapicuíba, Barueri e Jandira. ${ }^{7}$ Ou seja, a menor extensão pode significar alteração de escala, não mais o município, mas a integração metropolitana por meio da contiguidade das OUCs.

No caso de SBC, a questão é diferente, não só porque é realmente uma área muito extensa, mas também por recobrir praticamente toda a área passível de ser ocupada legalmente sem que as áreas de mananciais sejam invadidas. Pelo Plano Diretor de SBC (2011), o município está dividido em três Macrozonas: a Macrozona Urbana Consolidada (MUC), na sua porção norte; a Macrozona de Proteção Ambiental (MPA), no extremo sul; e a Macrozona de Proteção e Recuperação de Manancial (MPRM), espremida entre as duas primeiras.

O termo "espremida" não é figura de retórica, mas retrata fielmente o problema que está em andamento na área intermediária. E, mais uma vez, reforçará a especificidade da OUC de SBC, como trataremos adiante. Por ora, basta reter que o perímetro da OUC de SBC é quase todo coincidente com a área da Macrozona Urbana Consolidada.

Dissemos anteriormente que as OUCS não devem ser confundidas com experiências anteriores de articulação entre o poder público e o setor privado, como foram as Operações
Urbanas (1985) e as Operações Interligadas (1986). E o que permite dizer isso é a maior ou menor relação que cada legislação possui com as Habitações de Interesse Social (HIS). Ou seja, no caso de São Paulo, as HIS não são apenas um dos componentes da lei, passíveis de estarem ou não presentes. São indicadores da mudança do próprio sentido da lei ao longo do tempo. Desde a sua origem, as operações urbanas traziam uma relação estreita com a produção de moradias populares numa intenção evidente de se legitimar, mas também produzir uma forma mais equitativa de distribuição do solo urbano. Assim, se, por um lado, a lei era flexibilizada para garantir que o capital urbano pudesse aumentar seus rendimentos sobre o mesmo metro quadrado, por outro, pretendia reverter esse ganho do capital, deslocando-o para a produção de habitações de interesse social. De maneira muito diferente, as OUCs aprovadas na década de 1990, na cidade de São Paulo, pouco mencionam a habitação de interesse social e, se o fazem, é de maneira marginal (Carvalho, 2012). Portanto, no caso de São Paulo, as OUCs deixaram de manter relação direta com a HIS, expondo sua face mais privatista, na medida em que deixaram de ser meio de enfrentamento de um dos maiores problemas sociais das grandes cidades, o déficit de moradia popular. 
Figura 3 - Macrozoneamento de SBC (PD/2011)

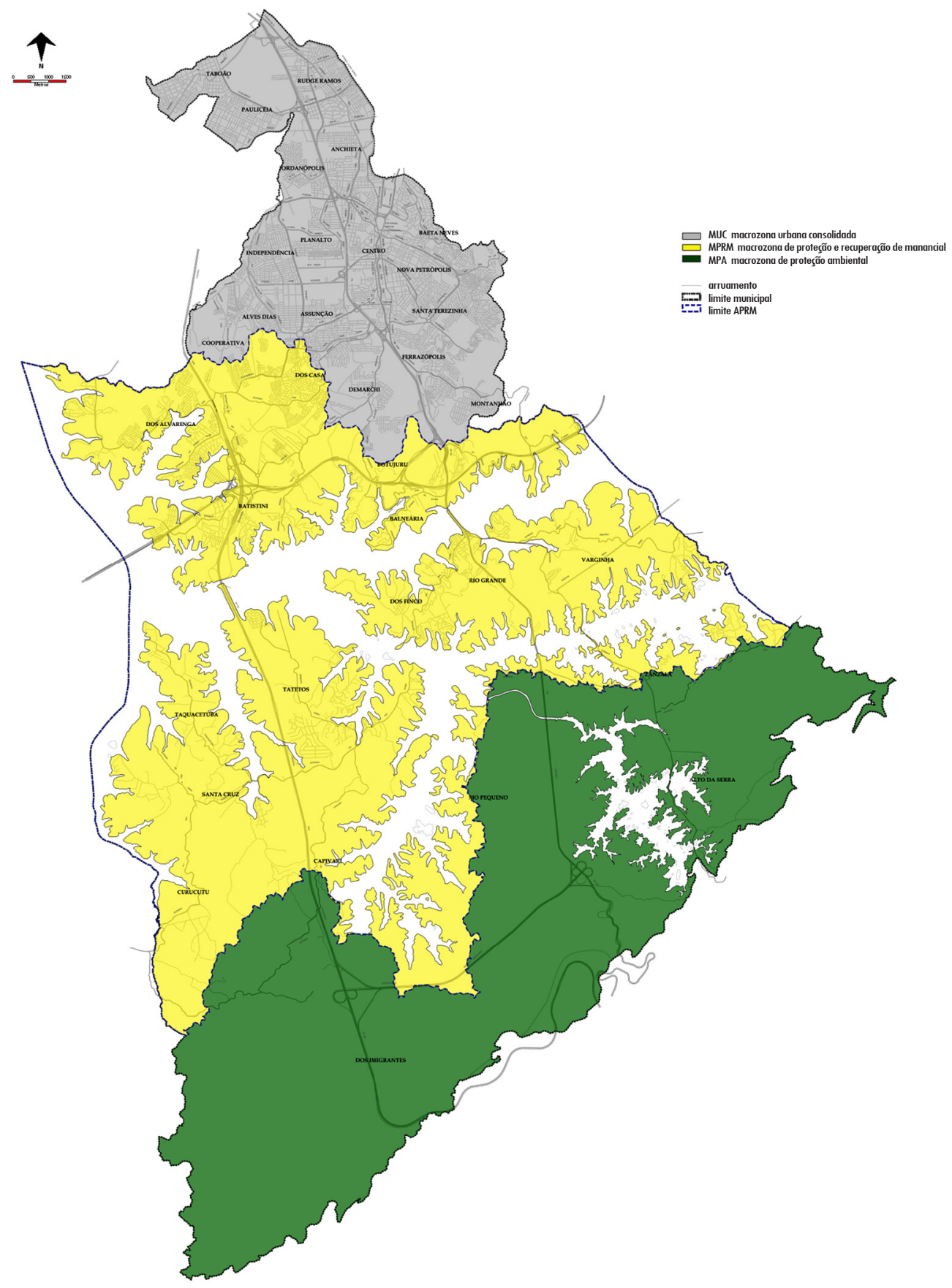

Fonte: Lei n. 6.184/2011 (Plano Diretor de SBC). 
Não se trata, portanto, apenas de observar se as HIS estão presentes ou não na legislação, mas considerá-las como o indicador por excelência do real sentido das OUCs, por meio do qual é possível perceber o quanto a balança pende a favor ou não do capital urbano. Tomando o objeto de pesquisa em questão e considerando esse indicador, é possível dizer desde já que estão em campos opostos a OUC Tietê de Osasco e a OUC de SBC.

A primeira impressão que se tem, ao comparar as legislações específicas dos municípios, é que a OUC de São Bernardo do Campo foi pensada como forma de obter recursos para resolver exatamente o problema de habitação popular no interior de seu perímetro, observação que, a princípio, pode parecer paradoxal e mesmo surpreendente, considerando que a maior parte das OUCs trata do tema de maneira periférica. Logo no Capítulo I, Seção I (Do conceito), art. 2으, $\S 1^{\circ}$, que trata dos objetivos do "planejamento, execução e fiscalização" da OUC, dois dos cinco itens listados mencionam a habitação de interesse social: o item II, que estabelece que a população diretamente afetada pela OUC deve ser atendida econômica e socialmente; e o item $\mathrm{V}$, que prevê a "regularização fundiária e a urbanização de áreas ocupadas por população de baixa renda no âmbito da OUC".

No $2^{\circ}$, em que estão dispostas as diretrizes da operação urbana, dos 22 itens existentes, três deles tratam das habitações "subnormais", seja para propor a regularização fundiária, seja para "promover a Habitação de Interesse Social e o atendimento à população residente em áreas objeto de desapropriação, necessárias à implantação dos melhoramentos previstos nesta Lei".
Se pode haver alguma dúvida de qual sentido haveria na menção à habitação de interesse social logo no primeiro capítulo da lei, mais adiante ela se desvanece, quando, nas Disposições Gerais (Seção III), estabelece que "o valor correspondente a $25 \%$ (vinte e cinco por cento) dos recursos advindos da Operação Urbana Consorciada serão utilizados para o desenvolvimento de ações de interesse social e inclusão urbana" que, por sua vez, deverão ser aplicados "exclusivamente" em "produção habitacional destinada ao reassentamento da população predominantemente de baixa renda residente em assentamentos precários ou irregulares" (item II); "urbanização integrada de assentamentos precários ou irregulares" (item III); "regularização fundiária de interesse social" (art. 6ㅇ § 1ㅇ).

A vinculação dos recursos obtidos por meio da operação urbana com a produção de habitação de interesse social e a regularização dos assentamentos subnormais é um dos fortes indícios de que a proposta de atender a população de baixa renda não é mera retórica, ideia que se confirma quando, em seu art. 6으 $\S 3$ o, define que os assentamentos precários deverão ser atendidos no perímetro da OUC e, não havendo essa possibilidade, no seu limite expandido, evitando que aqueles recursos sejam utilizados em áreas muito além do perímetro para o qual as intervenções de meIhoria urbana estão sendo planejadas. Essa regulamentação será reafirmada ao considerar, entre seus pressupostos, que "os reassentamentos realizados em função de deslocamento involuntário de local de moradia ou de atividade econômica pelas intervenções da Operação Urbana Consorciada deverão ocorrer no perímetro da Operação Urbana Consorciada" 
(art. 16) ou ainda, em seu art. 17, parágrafo único, em que explicita que "a implantação de unidades habitacionais de interesse social poderá ocorrer em todas as áreas da Operação Urbana Consorciada, nos termos da legislação municipal".

Esses elementos já seriam suficientes para demonstrar o quanto a questão da habitação de interesse social é central na estruturação da legislação específica da OUC de SBC, pois, já nos primeiros 17 artigos dos 66 existentes, está definida a relação da OUC com a HIS, com a destinação de parte dos seus recursos à promoção ou regularização de HIS, garantida a permanência da população de baixa renda no perímetro destinado às intervenções urbanas.

A articulação orgânica entre o instrumento urbanístico e a promoção de inclusão social fica mais evidente no momento em que a lei define os incentivos que serão concedidos a quem aderir à OUC. Assim, diz a lei:

será concedido o desconto de 10\% (dez por cento) na quantidade de Cepacs necessários para a outorga onerosa do potencial adicional de construção para empreendimentos imobiliários de grande porte que destinarem no mínimo $10 \%$ (dez por cento) da área construída computável desse empreendimento para habitação de interesse social, de acordo com os critérios de atendimento da Política Municipal de Habitação, ou que transferirem gratuitamente ao Município de São Bernardo do Campo empreendimento de habitação de interesse social, com respectivo habite-se, edificado em terreno localizado dentro da Operação Urbana Consorciada, em volume e área equivalente a $10 \%$ (dez por cento) da área construída computável do empreendimento de grande porte. (Art. 18, item III)
Ou ainda:

será concedido o desconto de 10\% (dez por cento) na quantidade de Cepacs necessários para a outorga onerosa do potencial adicional de construção, para empreendimentos imobiliários que destinarem no mínimo 30\% (trinta por cento) de suas unidades habitacionais para famílias com renda mensal de até 6 (seis) salários mínimos, de acordo com os critérios de atendimento da Política Municipal de Habitação. (Art. 18, item IV)

Além disso, a lei ainda faz menção às Zonas Especiais de Interesse Social já existentes no perímetro da OUC, garantindo que as disposições estabelecidas em sua lei própria prevaleceriam em relação à legislação da OUC SBC. Mais do que isso, a legislação seria objeto de revisão de modo a "garantir a manutenção das áreas delimitadas como de interesse social, de modo a mitigar os impactos da valorização imobiliária indicados no Estudo de Impacto de Vizinhança dessa Operação Urbana Consorciada" (art. 8ㅇ).

Muito diferente é a lei que institui a Operação Urbana Consorciada Tietê I, em Osasco. Se a expressão "habitação de interesse social" e suas derivadas aparecem 19 vezes na lei que regulamenta a OUC de São Bernardo do Campo, na correlata para Osasco não há mais que quatro menções, com duas incidências para a expressão propriamente dita - "habitações de interesse social" (na lei de SBC, são seis as menções da expressão em si). E essa pouca relevância dada à HIS não significa a ausência de moradia precária no perímetro definido pela OUC Tietê, ao contrário.

Com base no Estudo de Impacto de Vizinhança (EIV) elaborado pela Secretaria de Desenvolvimento Urbano (SDHU) de Osasco, 
no perímetro definido pela OUC, havia, no ano de 2008, 140 habitações "irregulares"; um aumento, segundo o mesmo documento, de $161 \%$ em relação ao ano de 2005 . Localizadas no Setor Militar, o rendimento médio mensal da população aí residente não excedia a 3 salários mínimos, situação não muito diferente do bairro Piratininga, também localizado no interior do perímetro da OUC, cujo rendimento variava entre 3 e 5 salários mínimos.

Portanto, estamos falando de uma área ocupada por uma população predominantemente de baixa renda, sem acesso - como também menciona o próprio documento - a qualquer infraestrutura urbana. Nos seus próprios termos: "na área da Operação Urbana Consorciada Tietê não existe infraestrutura instalada, sequer sistema viário, energia elétrica ou telefonia". Entretanto, a condição vulnerável da população e da área ocupada não foi suficiente para que houvesse no corpo da lei da OUC Tietê I um cuidado maior com esses assentamentos precários.

Embora a construção de habitação de interesse social seja um de seus objetivos, diferentemente da lei de SBC, ela vem sem qualquer destaque, associada a um conjunto de ações com o qual não possui qualquer relação direta, aliás, muito pelo contrário. Segundo a legislação, é objetivo da OUC Tietê I

promover o adensamento e a reestruturação da área pelo estabelecimento de novos padrões de uso e ocupação do solo, visando o controle do uso industrial, a oferta de empregos no setor terciário e de unidades residenciais, e a produção de habitações de interesse social para assentamento da população favelada residente no perímetro. (Art. 2으, item $\mathrm{X}$ )
Pela maneira como o texto está redigido, fica claro que o objetivo principal é, antes de tudo, a indução da reconversão econômica, criando empecilho para a instalação de novas plantas industriais e estimulando o desenvolvimento do setor de serviços. Ao mesmo tempo, fica evidente a clara oposição entre a intenção de promover "unidades residenciais" e "habitações de interesse social", apensadas ao final do período, quase que sugerindo seu acréscimo posterior.

No que diz respeito à reconversão econômica, não é preciso ir muito longe para perceber que esse é realmente o estímulo para a promulgação da OUC Tietê I, conforme dito, explicitamente, no Estudo de Impacto de Vizinhança (EIV). Segundo o documento, "Osasco foi uma cidade de intensa atividade industrial, mas, atualmente, o setor econômico de maior expressão é setor terciário: comércio e serviços". Além disso, segundo estudos produzidos pelo Sebrae, "com vários empresários da região oeste, do ponto de vista da logística locacional, Osasco é um município atrativo para a instalação de atividades econômicas e foi identificado como polo emergente para fixação de atividades desse segmento" (p. 17). Porém, ainda segundo o próprio documento, a própria morfologia do município, com o rio Tietê e a ferrovia cortando-o ao meio, produziu um território marcado pela "segregação espacial".

[Com] o deslocamento físico das atividades industriais para outras regiões [...] [e], seguindo as tendências predominantes, Osasco tem atraído, além de empresas de logística, sedes nacionais de empresas multinacionais, na região norte e na região central, escritórios diversos, faculdades, hotéis, centros distribuidores 
de mercadorias, shopping centers, conjuntos residenciais; estabelecimentos de instituições de ensino superior, havendo grande valorização imobiliária. (p. 17)

E continua dizendo que o mesmo, no entanto, não acontece com outras regiões, como aquelas abaixo do rio e da linha férrea: "outros bairros que compõem a região central expandida, tais como: Bonfim, parte do Rochdale e do km 18 merecem um tratamento e valorização semelhantes. Portanto, propõe-se para parte dessa região uma proposta de Operação Urbana Consorciada" (p. 18). 0 km 18 é onde estão localizados o Setor Militar e o bairro Piratininga, objetos da OUC Tietê I, e Bonfim, objeto da OUC Tietê II.

Assim, parece claro que o objetivo central da OUC Tietê I é estimular o investimento de novas atividades econômicas e, ao mesmo tempo, garantir a promoção de unidades residenciais não necessariamente voltadas à inclusão social. Pois, ao final do EIV, depois de demonstrada a vulnerabilidade da área sobre a qual se desenha a OUC Tietê I, não há qualquer recomendação para que sejam produzidas habitações de interesse social, embora não deixe de considerar que, uma vez constatada "a baixa densidade construtiva" da área estudada, assume a "segurança de propor o uso residencial".

Isso explica que, na lei propriamente dita, a habitação de interesse social apareça como um efeito colateral, marginal, periférico, como é mais usual na legislação voltada às OUCs desde a sua origem no município de São Paulo, evidenciada na transferência de sua solução para momento posterior, quando caberá, ao Comitê Gestor, "contribuir para a estruturação de programa de ação para a solução do problema das habitações subnormais existentes na área da Operação Urbana Consorciada Tietê" (art. 11, § 1으, item VI).

Por fim, se, na lei de SBC, há recursos da OUC vinculados à produção da HIS, nada é mencionado sobre essa relação na lei de Osasco, embora haja artigos que tratem do destino dos recursos auferidos com a OUC.

$\mathrm{Se}$, como exposto anteriormente, a maneira como a OUC se relaciona com a HIS é um indicador de seu maior ou menor favorecimento ao capital urbano, parece claro que a OUC Tietê I lhe favorece mais propriamente do que OUC de SBC. Em primeiro lugar, porque tem por objetivo explícito atrair o investimento privado, não só dos negócios ligados ao setor terciário, associado aos processos de reconversão econômica da economia globalizada, mas também o capital imobiliário, ao estimular a construção de unidades residenciais, por meio da criação de condições que Ihe sejam atrativas obras viárias, drenagem de terreno, instalação de infraestrutura urbana, etc. (cf. os objetivos da OUC Tietê I).

Mas há outro aspecto que revela seu caráter mais privatista: no caso da OUC Tietê I, os projetos a serem desenvolvidos no perímetro delimitado pelo poder público serão propostos pelos interessados ao Comitê Gestor que, por sua vez, com base nas diretrizes estabelecidas, promoverá sua aprovação, uma vez considerados todos os procedimentos. Ao contrário, na OUC de SBC, o protagonismo é todo ele do poder público, sobretudo na constituição de regulamentação extremamente detalhada, com vistas a delimitar claramente as ações do poder privado. 
A questão é saber o que pode explicar diferença tão significativa entre as operações urbanas propostas pelos dois municípios. Atribuir a posicionamentos ideológicos diversos dos partidos no poder municipal, embora pudesse ser a resposta mais provável, não se sustenta nesse caso, pois, nos dois municípios, no momento da elaboração e aprovação das OUC, o partido no poder era o PT: Emídio Pereira de Souza era o prefeito de Osasco, cargo que ocupou por dois mandatos seguidos (2005-2008/2009-2012), sendo sucedido por Antônio Jorge Pereira Lapas (2013-2016), originariamente do mesmo partido (em 2016, foi para o PDT). No caso de SBC, o prefeito era Luiz Marinho (2009-2016), também do Partido dos Trabalhadores.

Se é verdade que a filiação ao mesmo partido não se traduz necessariamente em posicionamentos semelhantes, querer sugerir que diversidade tão evidente no tratamento das operações urbanas se deva exclusivamente às personalidades dos prefeitos, obrigar-nos-ia a abandonar a hipótese mais forte que, sem dúvida, é a que interfere na diferenciação dos municípios em sua relação com o poder privado. Estou me referindo ao Consórcio do ABC.

Enquanto a vinculação de SBC ao Consórcio cria uma identidade regional que o fortalece no sentido de refrear os interesses do capital urbano, o isolamento de Osasco não lhe permite outro posicionamento senão aquele que o coloca tributário da marcha do capital originada em São Paulo. Não é casual que, em seu Estudo de Impacto de Vizinhança, Osasco seja "contextualizado" tendo por referência a capital e o seu posicionamento estratégico, considerando as interligações viárias, confirmando que se trata de atrair investimentos que estão para além de suas divisas. ${ }^{8}$ Em São
Bernardo do Campo, ao contrário, a motivação da OUC vem das iniciativas propostas pelo próprio Consórcio do $A B C$, a saber, a linha 18 do metrô que se, por um lado, é verdade que promove a integração com o município de São Paulo, facilitando o translado da população que lá trabalha, por outro, é exatamente para evitar que tal intervenção urbana promova valorização imobiliária sabidamente responsável pela exclusão social.

Portanto, se a OUC de Osasco está franqueando seu território à invasão do capital imobiliário que se origina em São Paulo, SBC atua no sentido de refreá-lo, ainda que mobilizado por uma obra responsável pela sua ligação mais estreita com o município-polo. Reforçam essa hipótese as datas em que as leis foram aprovadas: a de Osasco em 2008, em pleno boom imobiliário, a de SBC em 2015, depois do mesmo boom imobiliário que a afetou entre 2008 e 2013.

Conforme demonstrado no Estudo de Impacto de Vizinhança de SBC, no perímetro projetado para a OUC, foram "134 (cento e trinta e quatro) lançamentos imobiliários residenciais verticais", sendo 16 (dezesseis) empreendimentos na área de influência direta. No entorno expandido,

foram lançados 17 (dezessete) lançamentos imobiliários residenciais verticais. Nesse perímetro, foram lançados cerca de 13.379 apartamentos, tendo a produção imobiliária em termos de área útil lançada alcançado o montante aproximado de $1.150 .099 \mathrm{~m}^{2}$ e em termos monetários a quantia de $\mathrm{R} \$ \mathbf{7}, 105$ bilhões de reais. Importante destacar que, durante o período em análise, o consumo de terreno montou em cerca de 488.643,00 ${ }^{2}$. Em termos de valores médios, os apartamentos são comercializados por 
$\mathrm{R} \$ 328,2$ mil, ou seja, $\mathrm{R} \$ 4.376,00 / \mathrm{m}^{2}$. A área útil média dos apartamentos dentro do perímetro da Operação Urbana Consorciada de São Bernardo do Campo é de $75 \mathrm{~m}^{2}$. (p. 134)

Por sua vez, os "lançamentos não residenciais" na área da OUC, foram de apenas 12 (doze), com o lançamento de

2.514 conjuntos comerciais, tendo a produção imobiliária em termos de área útil lançada alcançado o montante aproximado de $92.727,00 \mathrm{~m}^{2}$ e em termos monetários a quantia em torno de $\mathrm{R} \$ 808,215$ milhões de reais. Importante destacar que durante o período em análise o consumo de terreno montou em cerca de $37.153,00 m^{2}$. Em termos de valores médios, os apartamentos são comercializados por $\mathrm{R} \$ 322,492$ mil, ou seja, $\mathrm{R} \$ 8.716,00 /$ $\mathrm{m}^{2}$. A área útil média dos apartamentos dentro do perímetro da Operação Urbana Consorciada de São Bernardo do Campo é de $37 \mathrm{~m}^{2}$. (EIV-SBC, p. 136)

Se, por um lado, a constatação do crescimento de lançamentos imobiliários em SBC possa ter despertado o interesse do município em se apropriar da mais-valia produzida por meio da OUC, por outro, considerando a centralidade que a HIS possui na sua legislação, pode ter sido antes um meio de refreá-lo, como a dizer que, se o capital imobiliário pretende invadir seu território, pelo menos o faça pagando ao município o que lhe é de direito e sem prejuízo da população que o habita, sobretudo a mais vulnerável.

Isso talvez explique por que a OUC de SBC abarque quase todo o município ou a chamada Macrozona Urbana Consolidada, pois que a edilidade conhece o que pode acontecer se o capital imobiliário penetrar ferozmente o seu território sem que o poder público o regulamente: a população vulnerável atingida migrará para as regiões de manancial, cuja necessidade de proteção mobilizou a primeira experiência de cooperação intermunicipal do País. Estamos, pois, de volta ao Consórcio do $\mathrm{ABC}$.

Podemos concluir, com base nas questões apresentadas inicialmente, que, nos dois casos, a OUC é mediação para obtenção de recursos destinados a suprir problemas fiscais dos municípios, decorrentes dos processos de reconversão econômica ocorridos em seus territórios. Da mesma forma, as OUCs transformam-se numa possibilidade, dada a fragilidade da regulamentação do governo central no que diz respeito ao desenvolvimento urbano, mesmo depois de aprovado o Estatuto da Cidade, permitindo que os municípios atuem conforme o jogo de forças locais. É nessa brecha que se insere a discussão do regime urbano, entendido aqui como a relação entre o setor público e o setor privado, pois que é o setor privado que pode prover os recursos necessários por meio da mais-valia gerada na produção de espaço urbano. No entanto, a maior ou menor imposição dos interesses privados sobre o poder público estará diretamente associada à maior ou menor articulação do poder público. No caso de SBC, a articulação no Consórcio do $A B C$ permitiu que a OUC atuasse muito mais no sentido de contenção do capital imobiliário do que em sua expansão. Diferentemente de Osasco, cuja legislação mais permissiva praticamente ignorou o território pregresso. E foi a HIS utilizada como indicador que evidenciou essa diferença.

Da mesma forma, são diferentes as escalas geográficas produzidas, sugerindo sentidos diferentes para a noção de região. Se, no caso de Osasco, a OUC produz por meio do capital 
a integração metropolitana, tendo o município de São Paulo como centralidade; no caso de SBC é a integração regional promovida pelo poder público que confronta a centralidade do município-polo exercida por meio da invasão promovida pelo capital imobiliário que tem, em seus limites, sua origem. No primeiro caso, ausência de identidade de Osasco submerso na região metropolitana. No segundo, a identidade regional do $A B C$ conferindo a SBC autonomia em relação ao município-polo. No primeiro caso, a história industrial de Osasco submersa na tendência terciária de metrópole; no segundo caso, a força industrial do $A B C$ constituindo diques às tendências de reconversão produzidas muito além dos seus limites.

\section{Considerações finais}

Por meio da análise comparativa dos marcos legais das OUCs de Osasco e São Bernardo do Campo, ambos localizados na RMSP, o objetivo deste artigo foi demonstrar a fecundidade da noção de regime urbano de maneira a fugir das interpretações agastadas que tendem para a pasteurização da relação entre poder público e capital urbano, tendendo sempre à determinação do segundo sobre o primeiro.
O estudo demonstrou que a articulação regional de SBC com os demais municípios do Consórcio do Grande $A B C$ pode ter sido a variável que fez diferença no confronto em relação à expansão do capital urbano sobre o território do município, variável ausente no município de Osasco, por sua vez, refém da escala geográfica imposta pela centralidade do capital imobiliário advindo do município de São Paulo. Dito de outra forma: o fato de SBC atuar numa escala regional pode ter sido o que lhe deu forças para confrontar o capital urbano, não no sentido de negá-lo, mas de regulamentá-lo visando a favorecer os interesses do município e dos seus moradores. Diferentemente, o território do município de Osasco foi alçado a outra escala, àquela dos interesses da economia global, em franco prejuízo dos seus munícipes. Se, no primeiro caso, o território do município é integrado, no segundo, é a fragmentação que se apresenta, pedaço projetado em outra escala que tem em Barueri o seu sentido.

Este estudo nos alerta sobre a importância do Estatuto da Metrópole que previu, em seu texto, as OUCs interfederativas. No entanto, com o veto ao Fundo Nacional de Desenvolvimento Integrado (FDI), a escala regional protagonizada pelo e nos interesses do mercado acaba por ser legitimada, mantendo os municípios reféns de seu isolamento federativo.

\section{[I] http://orcid.org/0000-0003-2391-6735}

Pontifícia Universidade Católica de São Paulo, Faculdade de Ciências Sociais, Departamento de Ciências Sociais. São Paulo, SP/Brasil.

Observatório das Metrópoles, núcleo São Paulo. São Paulo, SP/Brasil monicacarvalho@uol.com.br 


\section{Notas}

(*) Este artigo é resultado de pesquisa realizada no âmbito do Projeto a"As metrópoles e o direito à cidade: conhecimento, inovação e ação para o desenvolvimento urbano" - Programa de pesquisa da Rede Observatório das Metrópoles 2015-2020, sob a coordenação geral do Observatório das Metrópoles - INCT (IPPUR-UFRJ).

(1) "É alguma coisa que não se pode tocar com o dedo, ou tratar como o faz um agente vindo da tradição marxista que diz: 'O Estado faz isso', 'o Estado faz aquilo'. Eu poderia citar-lhes quilômetros de textos com a palavra 'Estado' como sujeito de ações, de proposições. É uma ficção absolutamente perigosa, que nos impede de pensar o Estado [...]. Para escapar à teologia, para poder fazer a crítica radical dessa adesão ao ser do Estado, que está inscrita em nossas estruturas mentais, é possível substituir o Estado pelos atos que podemos chamar de atos de 'Estado' - pondo 'Estado' entre aspas -, isto é, atos políticos com pretensões a ter efeitos no mundo social” (Bourdieu, 2014, pp. 45-46).

(2) "Os argumentos mais disseminados sobre a importância de empresas privadas são oriundos do marxismo. Essa perspectiva nos traz importantes insights sobre os circuitos de valorização e processos econômicos e políticos, mas essa interpretação foi sempre fortemente estruturalista e ligada à captura do Estado, não deixando muito espaço teórico para a contingência. Nesse sentido, construiu-se uma relação ambígua com a agência social, que é ao mesmo tempo valorizada como lutas, mas que nunca se tornam realmente efetivas, devido ao peso das estruturas. [...] O capital em geral e os interesses sistêmicos embasam a captura, tornando os atores políticos e as tão citadas lutas sem importância, visto que já sabemos o seu desfecho" (Marques, 2016, pp. 21-22).

(3) "Se nos dois países [França e Inglaterra] e sobretudo na Grã-Bretanha há uma proximidade com a situação americana no que diz respeito à fragmentação, as diferenças de estruturação das sociedades e da organização do poder permanecem demasiadamente importantes para que se possa, sem mais, importar conceitos" (Le Galés, 1995, p. 89; tradução da autora).

(4) Segundo Marques, "apenas nos anos 1970, formulações teóricas pluralistas de destaque começaram a ressaltar a desproporção de recursos de poder entre os atores, sugerindo uma maior probabilidade de vitória para atores empresariais privados da cidade" (Marques, 2016, p. 23). Da mesma década, mais precisamente 1976, é o texto de Harvey Molotch, publicado pela primeira vez no American Journal of Sociology.

(5) Há uma discussão bastante intensa no campo da economia sobre esse tema e que não temos condições de reproduzir aqui. Para uma síntese dessa discussão e sua tradução na cidade de São Paulo, cf. Carvalho et al. (2018, pp. 83-129).

(6) Deixaremos de lado o termo "parceria" que já contém, em si, uma determinação a favor do capital urbano. Partiremos da premissa de que a parceria, se houver, será definida pela pesquisa empírica.

(7) Não vamos discutir essa hipótese neste artigo, o que será feito posteriormente quando a pesquisa tiver avançado para os demais municípios. 
(8) “Osasco localiza-se na região oeste da Região Metropolitana de São Paulo, conforme demonstrado no mapa 1, estendendo-se ao longo do vale do Rio Tietê iniciando-se próximo à confluência deste com o Rio Pinheiros. O centro de Osasco está a 18 km da Praça da Sé em São Paulo, considerando-se o menor percurso. Está localizado, privilegiadamente, próximo à capital, e possui acessos importantes através da Rodovia Anhanguera, Rodovia Castello Branco, Rodovia Raposo Tavares, Estrada de Ferro operada pela Companhia Paulista de Trens Metropolitanos CPTM e o recém-inaugurado Rodoanel Mário Covas, além do Rio Tietê que secciona a cidade no sentido leste-oeste" (EIV-Osasco, 2008).

\section{Referências}

ABRUCIO, F. L.; SOARES, M. M. (2001). Redes Federativas no Brasil: cooperação intermunicipal no Grande $A B C$. São Paulo, Fundação Konrad Adenauer (Série Pesquisas n. 24).

ARRETCHE, M. (2012). Democracia, federalismo e centralização no Brasil. Rio de Janeiro, Editoras FGV e Fiocruz.

BOURDIEU, P. (2009). “Le mort saisit le vif: as relações entre a história reificada e a história incorporada”. In: BOURDIEU, P. O poder simbólico. Rio de Janeiro, Bertrand Brasil.

(2014). Sobre o Estado. São Paulo, Companhia das Letras.

CARLOS, A. F. A. (2014). “Da 'organização' à 'produção' do espaço no movimento do pensamento geográfico”. In: CARLOS, A. F.; SOUZA, M. L.; SPOSITO, M. E. B. (orgs.). A produção do espaço urbano: agentes e processos, escalas de desafios. São Paulo, Contexto.

CARVALHO, M. et al. (2018). “Desindustrialização na cidade de São Paulo: consequências para o mercado de trabalho da Zona Leste da cidade". In: OLIVEIRA, A. C. de; JUNQUEIRA, M. A. WANDERLEY, M. B. (eds.). Constelações urbanas: territorialidades, fluxos, manifestações estético-políticas. São Paulo, Educ - Editora da Pontifícia Universidade Católica de São Paulo, pp. 83-129.

CARVALHO, M. (2000). Cidade global: anotações críticas de um conceito. São Paulo em Perspectiva, v. 14, n. 4, out/dez.

(2012). “A 'captura' da Zona Especial de Interesse Social: duplo significado da conquista”. In: BAPTISTA, D. M. T.; GAGLIARDI, C. M. R. (orgs.). Intervenções urbanas em centros históricos: Brasil e Itália em discussão. São Paulo, Educ.

CASTELLS, M. (2008). “O espaço de fluxos”. In: CASTELLS, M. Sociedade em rede. Rio de Janeiro, Paz e Terra.

FERREIRA, J. W.; MARICATO, E. (2002). “Operação urbana consorciada: diversificação urbanística participativa ou aprofundamento da desigualdade?”. In: OSÓRIO, L. M. (org.). Estatuto da cidade e reforma urbana: novas perspectiva para as cidades brasileiras. Porto Alegre, Sérgio Antônio Fabris.

FIX, M. (2007). São Paulo cidade global: fundamentos financeiros de uma miragem. São Paulo, Boitempo.

HALL, P. (2011). “A cidade do empreendimento”. In: HALL, P. Cidades do amanhã. São Paulo, Perspectiva.

LE GALÈS, P. (1995). Du gouvernement des villes à la gouvernance urbaine. Revue française de science politique, $45^{\mathrm{e}}$ année, n. 1. pp. 57-95. 
MALERONKA, C.; HOBBS, J. A. (2017). Operações Urbanas: o que podemos aprender com a experiência de São Paulo? Washington, DC, Banco Interamericano de Desenvolvimento (BID). Disponível em: https://publications.iadb.org/pt/node/16265. Acesso em: 19 ago 2018.

MARICATO, E. (2000). "As ideias fora do lugar e o lugar fora das ideias". In: ARANTES, O. F., WAINER, C.; MARICATO, E. A cidade do pensamento único: desmanchando consensos. Petrópolis, Vozes.

MARQUES, E. (2016). De volta aos capitais para melhor entender a política urbana. Novos Estudos Cebrap. São Paulo, v. 35, n. 2, pp. 15-23.

MOLOTCH, H. (1976). The city as a growth machine: toward a political economy of place. American Journal of Sociology, v. 82, n. 2, pp. 309-332.

MOSSBERGER, K.; STOKER, G. (2001).The evolution of regime theory. Urban Affairs Review, n. 36, n. 6, pp. 810-835.

SASSEN, S. (1998). As cidades na economia mundial. São Paulo, Studio Nobel.

SMITH, N. (2000). "Contornos de uma política especializada: veículos dos sem-teto e produção da escala geográfica". In: ARANTES, A. (org.). O espaço da diferença. Campinas, Papirus.

SPOSITO, M. E. B. (2014). “A produção do espaço urbano: escalas, diferenças e desigualdades socioespaciais". In: CARLOS, A. F.; SOUZA, M. L.; SPOSITO, M. E. B. (orgs.). A produção do espaço urbano: agentes e processos, escalas de desafios. São Paulo, Contexto.

STONE, C. (1993). Urban regimes and the capacity to govern: a political economy approach. Journal of Urban Affairs, v. 15, n. 1, pp. 1-28.

\section{Legislação pesquisada}

Lei n. 13.430/2002 (Plano Diretor Estratégico da Cidade de São Paulo)

Lei complementar n. 170 de 16 janeiro de 2008, regulamentada pelos decretos n. 9968/2008 e n. 11099/2015 (OUC Tietê I)

Lei complementar n. 203 de 22 de dezembro de 2010 (OUC Tietê II)

Lei n. 6.403 de 22 de junho de 2015 (OUC SBC)

Lei n. 6.184/2011 (Plano Diretor de SBC)

Lei n. 13.089 de 12 de janeiro de 2015 (Estatuto da Metrópole)

Decreto n. 56.901/2016 (Projeto de Intervenção Urbana - São Paulo)

\section{Sites}

IBGE. Disponível em: Cidadeshttps://cidades.ibge.gov.br/

Gestão Urbana. Disponível em: https://gestaourbana.prefeitura.sp.gov.br/

Texto recebido em 16/jun/2019

Texto aprovado em 21/ago/2019 